\title{
Seasonal Effects on Photosynthetic Pigments, Nutrients, Flavonoids, Polyphenol and Antioxidant Activity of Abrus precatorius L. (Kunch)
}

\begin{abstract}
Mohammed Sala Uddin ${ }^{1 *}$, M. Saroar Jahan ${ }^{2}$ and K. M. Mesbaul Alam ${ }^{3}$
${ }^{1}$ Associate Professor, ${ }^{2}$ Student of MS (Thesis), ${ }^{3}$ Professor, Department of Botany, University of Chittagong, Chattogram-4331, Bangladesh

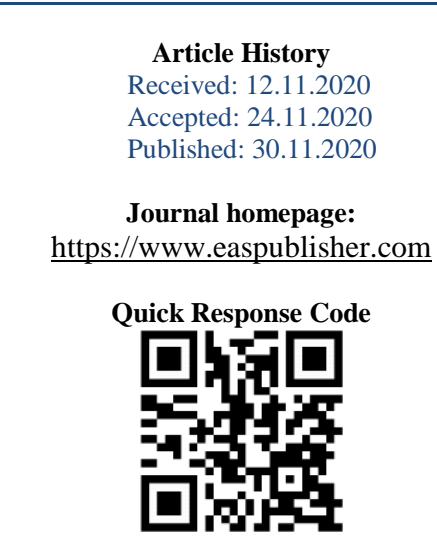

Abstract: Seasonal effects on photosynthetic pigments, nutrients, flavonoids, and
polyphenol and antioxidant activities of Abrus precatorius L. were studied in three different
growing seasons within a year. An experiment was conducted during January, 2019 to March,
2020 at the Botanical Garden, University of Chittagong. The highest foliar photosynthetic
pigments, nutrients were observed in monsoon (June-August) and the lowest in late
monsoon (September-November) whilst maximum flavonoid content was determined in the
leaf extract of early monsoon (March-May) and minimum in late monsoon (September-
November) respectively. In contrast the highest polyphenol content and antioxidant activity
were estimated in the leaf extract of late monsoon (September-November) and minimum in
early monsoon (March-May) respectively. The present study concludes that monsoon
(June-August) is suitable for efficient photosynthesis as well as nutrient accumulation in
Abrus and early monsoon (March-May) is favourable for flavonoid synthesis. Considering
the amount of the all studied elements late monsoon (September-November) is the right
time for harvesting the leaves of Abrus to be obtained maximum polyphenol and
antioxidant activity for medicinal use.
Keywords: Seasonal effect, Kunch, pigments, nutrients, flavonoids, polyphenols,
antioxidant.
\end{abstract}

Copyright ( ) 2020 The Author(s): This is an open-access article distributed under the terms of the Creative Commons Attribution 4.0 International License (CC BY-NC 4.0) which permits unrestricted use, distribution, and reproduction in any medium for non-commercial use provided the original author and source are credited.

\section{INTRODUCTION}

Abrus precatorius L. is an ornamental, rare, perennial, twinning, deciduous woody medicinal vine belonging to family Fabaceae normally known as kunch in Bengali [1-4]. Southeast Asia is the place of origin of this plant [5]. It is one of the most impressive medicinal plant $[6,2]$. It has diverse biological activity viz. anticancer [7, 8], anti-diabetic [9, 10], antiinflammatory [11, 12], anti-fertility [13, 14], antioxidant [15, 16], nephroprotective [17], neuroprotective [18], antimalarial [19], cytotoxic [20], pest management [21], anti-microbial $[22 ; 23]$ and anti-viral $[24,25]$. The leaf of Abrus precatorius is the source of different alkaloids [26], flavonoids [27], tri-terpenoids [28], carbohydrates and amino acids [29]. Roots and leaves of this plant carry sweet tasting glycyrrihizin [30, 2].

So far the literature review is concerned; no specific study has yet been done on the dynamics of active components in Kunch plant in respect to seasons and habitats in Bangladesh. The present study was undertaken to assess the seasonal effect on foliar photosynthetic pigments, nutrients, flavonoids, and polyphenol and antioxidant activity of Abrus precatorius L. in three different growing seasons.

\section{Materials AND Methods}

The experimental plant samples (leaf of Abrus precatorius L.) were collected in three different seasons (EM: Early monsoon - March, April and May; M: Monsoon-June, July and August; LM: Late MonsoonSeptember, October and November) from the Botanical garden, University of Chittagong. Leaves were dried in the laboratory under current air at room temperature $\left(28^{0} \mathrm{C}\right)$ and then after twenty four hours the materials were put in to the oven maintained at $60^{\circ} \mathrm{C}$ for 48 hours. All the samples were then weighed in an electric balance and ground to pass through $0.2 \mathrm{~mm}$ sieve and preserved in airtight plastic vial for analysis.

Foliar photosynthetic pigments were determined by Wettstein method [31]. For this purpose fresh leaves (3rd and 4th pairs) were collected from the plants. Foliar nutrients (viz. N, P and $\mathrm{K}$ ) were extracted with sulfuric-peroxide $\left(\mathrm{H}_{2} \mathrm{SO}_{4}+\mathrm{H}_{2} \mathrm{O}_{2}\right)$ digestion mixture and determined by standard method [32]. The foliar iron content was determined by spectrophotometric method [33]. The foliar protein content was measured sensitive spectrophotometric method [34]. Flavonoids was measured using an UV-visible spectrophotometric (Shimadzu UV-160A PC, Shimadzu Corporation, Kyoto, Japan) method [35]. The polyphenol content was measured based on Roberts [26] with modification 
from the recent work of some researchers [37, 38]. The radical scavenging activity of the leaf extracts was determined by the 2, 2-diphenyl-2-picrylhydrazyl (DPPH) radical using a modified method [39]. The assay is based on the measurement of the scavenging ability of antioxidants towards the stable DPPH radical [40]. There were three replications for each set of experiment. Experiments were designed on CRD method. Statistical analyses were done according to MS excel.

\section{RESUlT AND DisCUSSION}

The results (Table-1, Fig.1) reveal that the foliar photosynthetic pigments varied with the change of seasons. Chlorophyll-a, Chlorophyll-b, Carotenoids, total chlorophyll and total pigments ranged from 3.262 $\mathrm{mgg}^{-1} \mathrm{FW}$ (Monsoon) to $2.045 \mathrm{mgg}^{-1} \mathrm{FW}$ (Late Monsoon); $1.372 \mathrm{mgg}^{-1} \mathrm{FW}$ (Early Monsoon) to 0.827 $\mathrm{mgg}^{-1} \quad \mathrm{FW}$ ( Late Monsoon); $1.010 \mathrm{mgg}^{-1}$ FW (Monsoon) to $0.640 \mathrm{mgg}^{-1} \mathrm{FW}$ (Early Monsoon); 4.518 $\mathrm{mgg}^{-1} \mathrm{FW}$ (Monsoon) to $2.873 \mathrm{mgg}^{-1} \mathrm{FW}$ (Early Monsoon) and $5.528 \mathrm{mgg}^{-1} \mathrm{FW}$ (Monsoon) to 3.759 $\mathrm{mgg}^{-1}$ FW (Late Monsoon) respectively and chlorophyll-a, total chlorophyll and total pigments showed the following trend as M>EM>LM. ANOVA of foliar pigments (Chl-a, Chl-b, Car and total Chl) and total pigments showed significant value $(\mathrm{P}<0.01)$ with seasons (Table-1, 3). Charu and Vandana [41] observed maximum chlorophyll-content in monsoon and minimum in late monsoon in Jatropa curcas and Acacia nilotica. Shinde et al. [42] showed maximum chlorophyll-b content in early monsoon and minimum in late monsoon in the leaf of Rauwolfia serpentine, Santalum album and Adhatoda vasica. Sauceda et al. [43] enumerated maximum carotenoids content in monsoon and minimum in early monsoon in Acacia regidula and Prosopis laevigata. Prajapati and Tripathi [44] observed maximum total chlorophyll content in monsoon and minimum in late monsoon in the leaf of Ficus religiosa, Mangifera indica, Psidium guajava and Dalbergia sissoo. In case of plucked shoots of clonal agrotypes of tea and kalomegh, photosynthetic total pigments were found to be changed with plucking seasons and maximum value was obtained in monsoon $[48,55]$ which are similar to this finding.

The results of foliar nutrients viz. Nitrogen, Phosphorus, Potassium, Iron and Protein are shown in Table 2. Foliar Nitrogen, Phosphorus, Potassium and protein contents ranged from $1.022 \%$ (Monsoon) to $0.6392 \%$ (Late Monsoon); $0.0687 \%$ (Monsoon) to $0.0337 \%$ (Late Monsoon); $0.9886 \%$ (Monsoon) to $0.4688 \%$ (Late Monsoon); and $6.387 \%$ (Monsoon) to $3.995 \%$ (Late Monsoon); respectively and showed the following sequence as $\mathrm{M}>\mathrm{EM}>\mathrm{LM}$. Foliar Iron contents varied from $0.0594 \%$ (Early Monsoon) to $0.0268 \%$ (Late Monsoon) and showed the following trend as EM $>$ M $>$ LM. ANOVA of foliar N, P, K, Fe and protein showed significant value $(\mathrm{P}<0.01)$ with seasons (Table2). Patarapanich et al. [45] and Uddin et al. [46] reported that the foliar nutrients of Andrographis paniculata changed with seasons as well as growing conditions. These reports also bear a resemblance to the findings of the present experiment.

Table-1: Change of foliar pigments of Abrus precatorius $\mathrm{L}$. in three different seasons

\begin{tabular}{|c|c|c|c|c|c|c|c|}
\hline \multirow{2}{*}{ Seasons } & \multicolumn{3}{|c|}{ Pigments, mg/g FW } & \multicolumn{3}{c|}{ Ratio of pigments } \\
\cline { 2 - 8 } & Chl-a & Chl-b & Car & $\begin{array}{c}\text { Total } \\
\text { Chl }\end{array}$ & Chl-a/Chl-b & Chl-a/Car & Chl/Car \\
\hline EM & $2.198^{\mathrm{b}}$ & $1.372^{\mathrm{a}}$ & $0.640^{\mathrm{b}}$ & $3.570^{\mathrm{b}}$ & $1.624^{\mathrm{a}}$ & $3.440^{\mathrm{a}}$ & $5.61^{\mathrm{a}}$ \\
& \pm 0.10 & \pm 0.18 & \pm 0.05 & \pm 0.08 & \pm 0.27 & \pm 0.11 & \pm 0.55 \\
\hline M & $3.262^{\mathrm{a}}$ & $1.257^{\mathrm{a}}$ & $1.010^{\mathrm{a}}$ & $4.518^{\mathrm{a}}$ & $2.637^{\mathrm{a}}$ & $3.235^{\mathrm{a}}$ & $4.49^{\mathrm{b}}$ \\
& \pm 0.07 & \pm 0.18 & \pm 0.06 & \pm 0.11 & \pm 0.44 & \pm 0.13 & \pm 0.37 \\
\hline LM & $2.045^{\mathrm{b}}$ & $0.827^{\mathrm{b}}$ & $0.886^{\mathrm{a}}$ & $2.873^{\mathrm{c}}$ & $2.629^{\mathrm{a}}$ & $2.316^{\mathrm{b}}$ & $3.27^{\mathrm{c}}$ \\
& \pm 0.09 & \pm 0.23 & \pm 0.08 & \pm 0.14 & \pm 0.86 & \pm 0.12 & \pm 0.47 \\
\hline F value & $171.2^{* *}$ & $6.45^{*}$ & $24.29^{* *}$ & $167.2^{* *}$ & $3.004^{\mathrm{ns}}$ & $77.71^{* *}$ & $18.33^{* *}$ \\
\hline
\end{tabular}

Legend: $\mathrm{Chl}=$ Chlorophyll; $\mathrm{Car}=$ Carotenoids; $* *=$ Significant at $1 \%$ level; $*=$ Significant at $5 \%$ level; ns= Non-significant; FW= Fresh weight. In each rows, values with same superscript are non-significant and with different superscript are significant by DMRT (Duncan Multiple Range Test).

Table-2: Change of foliar nutrients of Abrus precatorius $\mathbf{L}$. in three different seasons.

\begin{tabular}{|c|c|c|c|c|c|}
\hline \multirow{2}{*}{ Seasons } & \multicolumn{5}{|c|}{ Nutrients } \\
\cline { 2 - 6 } & Nitrogen (\%) & Phosphorus (\%) & Potassium (\%) & Iron (\%) & Protein (\%) $^{\text {(\%) }}$ \\
\hline EM & $0.8782^{\mathrm{b}}$ & $0.0492^{\mathrm{b}}$ & $0.7250^{\mathrm{b}}$ & $0.0594^{\mathrm{a}}$ & $5.887^{\mathrm{b}}$ \\
& \pm 0.011 & \pm 0.002 & \pm 0.06 & \pm 0.004 & \pm 0.071 \\
\hline M & $1.022^{\mathrm{a}}$ & $0.0687^{\mathrm{a}}$ & $0.9886^{\mathrm{a}}$ & $0.0357^{\mathrm{b}}$ & $6.387^{\mathrm{a}}$ \\
& \pm 0.073 & \pm 0.003 & \pm 0.11 & \pm 0.002 & \pm 0.081 \\
\hline LM & $0.6392^{\mathrm{c}}$ & $0.0337^{\mathrm{c}}$ & $0.4688^{\mathrm{c}}$ & $0.0268^{\mathrm{c}}$ & $3.996^{\mathrm{c}}$ \\
& \pm 0.012 & \pm 0.002 & \pm 0.03 & \pm 0.001 & \pm 0.076 \\
\hline F-value & $47.26^{* *}$ & $72.62^{* *}$ & $25.57^{* *}$ & $71.34^{* *}$ & $51.65^{* *}$ \\
\hline
\end{tabular}

Legend: $\mathrm{EM}=$ early monsoon; $\mathrm{M}=$ Monsoon; LM= Late monsoon; DW= dry weight; **denotes significant at $1 \%$ level in ANOVA. In each column, values with same superscript are non-significant and with different superscript are significant by DMRT (Duncan Multiple Range Test). 
Table-3: Analyses of variance of total pigments, flavonoids, polyphenol and antioxidant content in leaf of $\mathrm{Abrus}$ precatorius $\mathrm{L}$. in three different seasons

\begin{tabular}{|c|c|c|c|c|c|}
\hline Source of variance & Degree of freedom & \multicolumn{4}{|c|}{ F-values } \\
\cline { 3 - 6 } & & Total pigments & Flavonoids & Polyphenol & Antioxidant \\
\hline Seasons & 2 & $124.6^{* *}$ & $17.66^{* *}$ & $61.81^{* *}$ & $63.76^{* *}$ \\
\hline Error & 6 & - & - & - & - \\
\hline
\end{tabular}

Legend: ** denotes significant at $1 \%$ level.

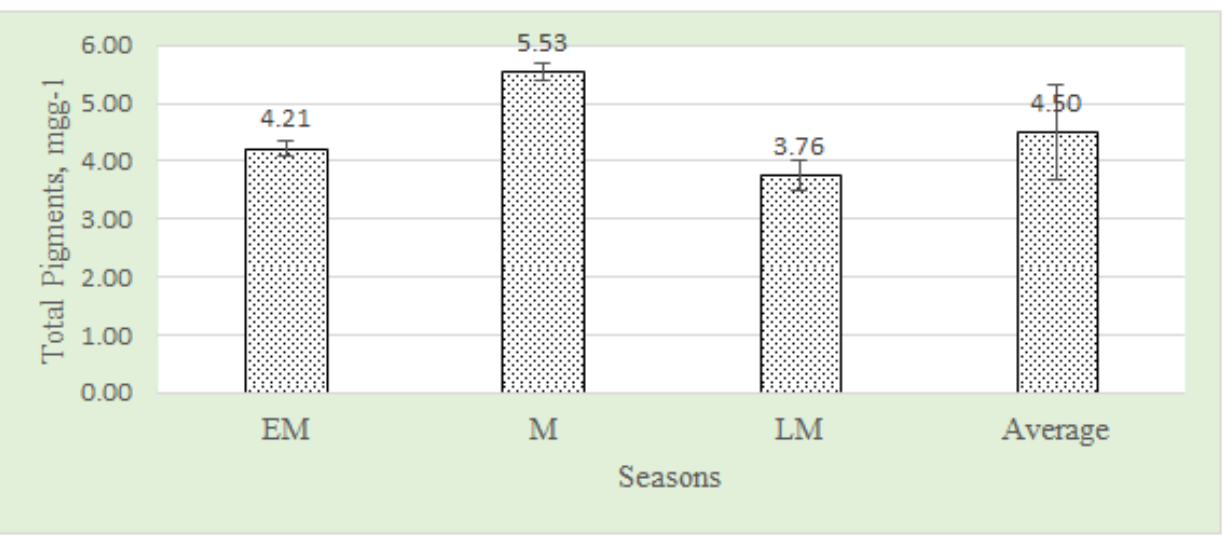

Fig-1: Change of total foliar pigments of Abrus precatorius $\mathbf{L}$. in three different seasons.

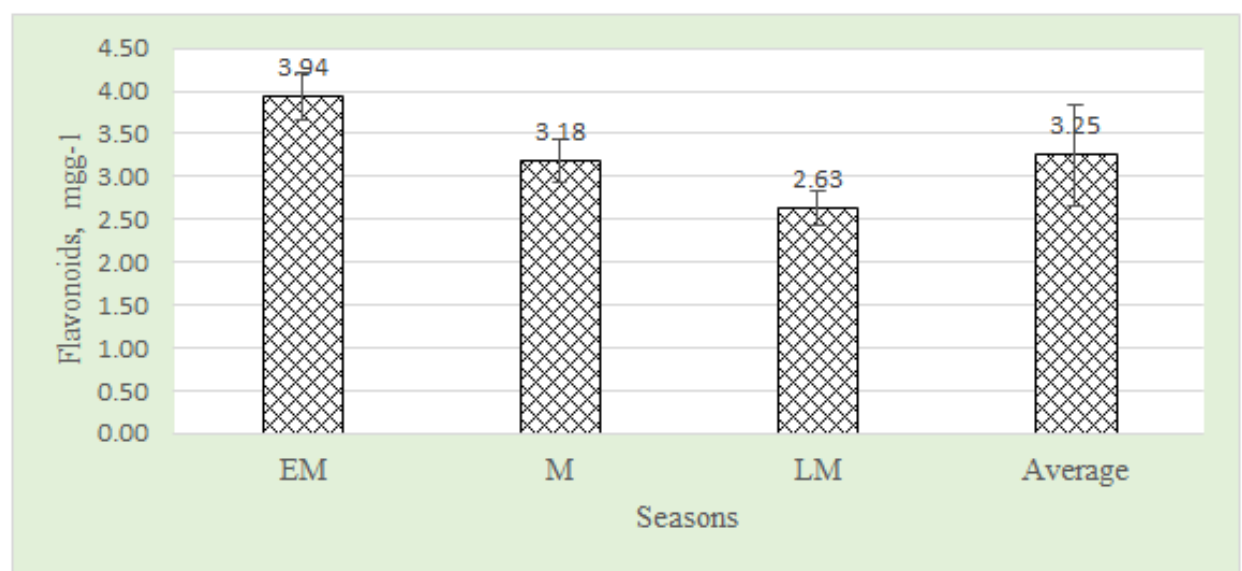

Fig-2: Change of flavonoids in the leaves of Abrus precatorius L. in three different seasons

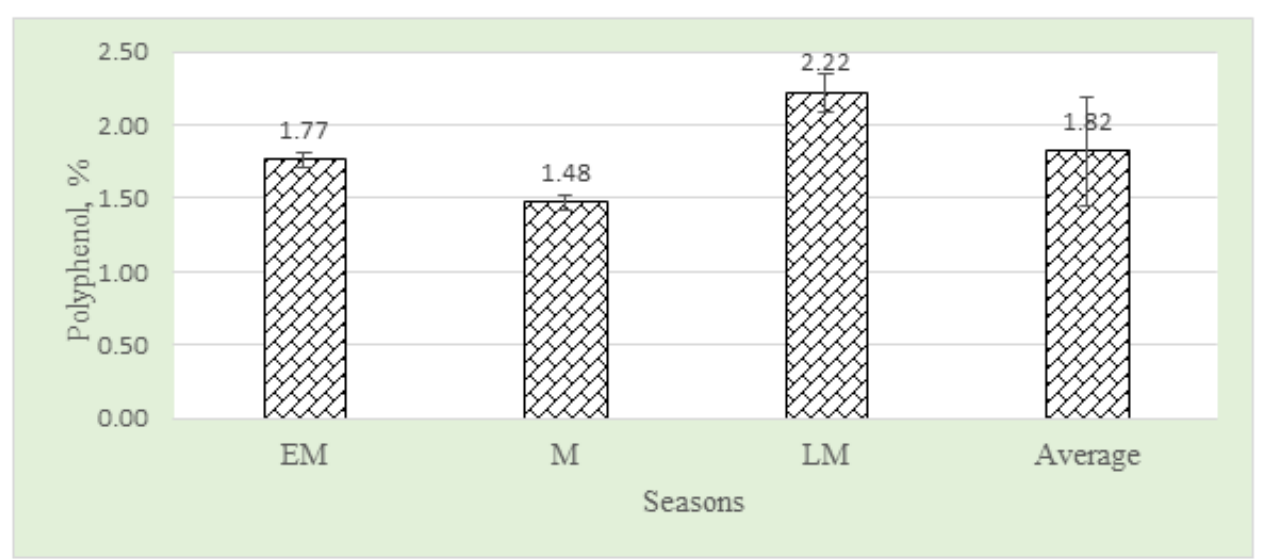

Fig-3: Change of polyphenol content in the leaves of Abrus precatorius L. in three different seasons 


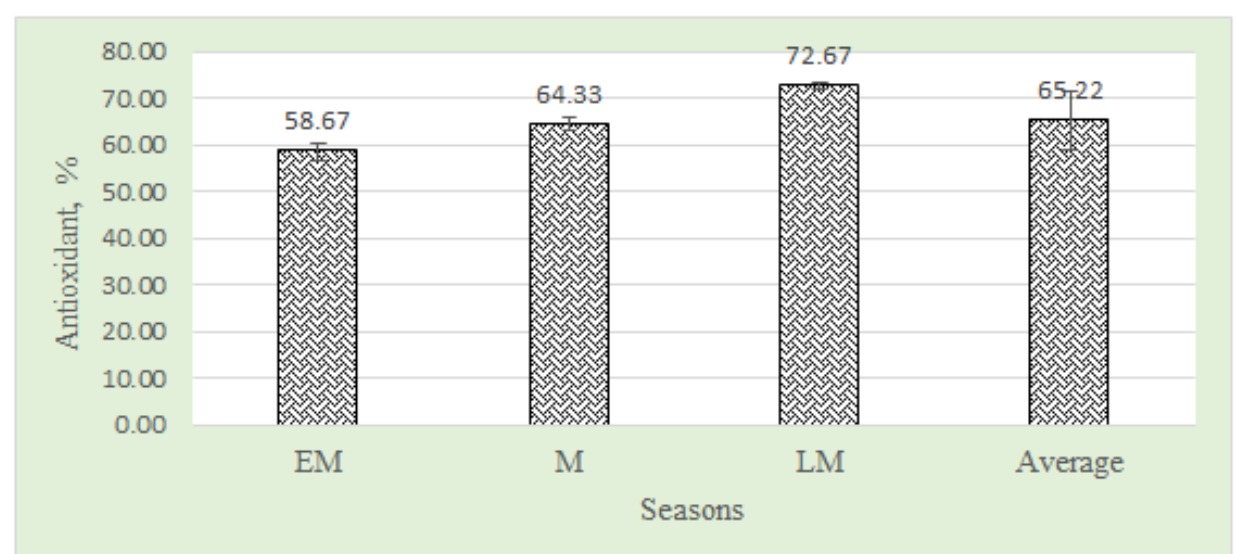

Fig-4: Change of antioxidant activity in the leaves of Abrus precatorius L. in three different seasons

The results of flavonoid contents are exposed in Fig. 2. Foliar flavonoid contents varied from 3.94 $\mathrm{mgg}^{-1}$ DW (Early Monsoon) to $2.63 \mathrm{mgg}^{-1}$ DW (Late Monsoon) and showed the following trend as EM $>M>L M$. ANOVA of flavonoid contents showed significant value $(\mathrm{P}<0.01)$ with seasons $($ Table- 3$)$. Zhu et al. [47] reported that the highest content of total flavonoids of Vaccinium ashei leaves was obtained in the month of May (Early Monsoon). Cezarotto et al. $[48,54]$ observed that the highest content of total flavonoids of Vaccinium ashei leaves was obtained in the month of April (Early Monsoon) which corroborate with this finding.

The results of polyphenol contents are presented in Fig. 3. Foliar polyphenol contents ranged from $2.223 \%$ (Late Monsoon) to $1.475 \%$ (Monsoon) and showed the following succession as $L M>E M>M$. ANOVA of foliar polyphenol showed significant value $(\mathrm{P}<0.01)$ with seasons (Table-3). Polyphenol content was maximum in late monsoon and minimum in monsoon. Wahba et al., [49] in Cynara cardunculus noticed maximum polyphenol in early monsoon (May) than monsoon (June). A possible cause of maximum polyphenol content in late monsoon and minimum in monsoon due to the enzyme polyphenol oxidase (PPO) shows the high activity in monsoon (rainy season) and minimum activity in late monsoon suggested by Thakur and Kapila [50]. In liverworts Thakur \& Kapila [50] estimated maximum phenolic content in winter (late monsoon) and minimum in rainy season (monsoon). Liao et al. [51] determined maximum phenolic content in winter (late monsoon) in the shoot extract of Oxalis corymbosa which are analogous to this finding.

The results of antioxidant activity are displayed in Fig. 4. Foliar antioxidant activity varied from $72.67 \%$ (Late Monsoon) to $58.67 \%$ (Early Monsoon) and showed the following progression as $\mathrm{LM}>\mathrm{M}>\mathrm{EM}$. ANOVA of foliar antioxidant activity showed significant value $(\mathrm{P}<0.01)$ with seasons (Table3). Zhu et al., [47] showed that the rabbiteye blueberry leaves from November had the highest antioxidant capacity and Rekha et al., [52] and Cao et al., [53] also showed that one of the maximum antioxidant activities was obtained in the month of November (Late Monsoon) in the leaf extracts of Ligularia fischeri and Cyclocarya paliurus respectively. These observations are consistent with the present findings.

\section{CONCLUSION}

The present study concludes that monsoon (June-August) is suitable for efficient photosynthesis as well as nutrient accumulation in Abrus and early monsoon (March-May) is favourable for flavonoid synthesis. Considering the amount of all studied elements late monsoon (September-November) is the right time for harvesting the leaves of Abrus precatorius to be obtained maximum polyphenol and antioxidant activity for medicinal use.

\section{ACKNOWLEDGMENT}

The authors are thankful to the Department of Botany, University of Chittagong for providing all sorts of required facilities to conduct this research.

\section{REFERENCES}

1. Rahman, M. A. (2017). Plant diversity in Hazarikhil Wildlife Sanctuary of Chittagong and its conservation management. Journal of Biodiversity Conservation and Bioresource Management, 3(2), 43-56.

2. Okhale, S. E., \& Nwanosike, E. M. (2016). Abrus precatorius Linn (Fabaceae): phytochemistry, ethnomedicinal uses, ethnopharmacology and pharmacological activities. Int J Pharm Sci Res, 1, 37 43.

3. Rahman, A. H. M. M., \& Parvin, M. I. A. (2015). Taxonomic Studies on the family Fabaceae (Weeds) at Rajshahi University Campus. Plant, 3(3), 20-25.

4. Animesh, B., Roy, M., \& Bhadra, M. B. M. S. (2007). In vitro Propagation of Abrus precatorius L. A Rare Medicinal Plant of Chittagong Hill Tracts. Plant Tissue Cult. \& Biotech, 17(1), 59-64.

5. Prabha, M., Perumal, C., \& Kumar, P. (2015). Soundarrajan, S Srinivasan, et al. Review Article Pharmacological activities of Abrus precatorius (L.) seeds. International Journal of Pharmaceutical and 
Medicinal Research Journal homepage,3(2), 195200.

6. Bhakta, S., \& Das, S. K. (2020). The medicinal values of Abrus precatorius: a review study. Journal of Advanced Biotechnology Experimental Therapeutics, 3(2): 84-91.

7. Lebri, M., Tilaoui, M., Bahi, C., Achibat, H., Akhramez, S., Fofie, Y. B. N., \& Zyad, A. (2015). Phytochemical analysis and in vitro anticancer effect of aqueous extract of Abrus precatorius Linn. Der Pharma Chemica, 7(8), 112-117.

8. Ghosh, D., \& Maiti, T. K. (2007). Immunomodulatory and anti-tumor activities of native and heat denatured Abrus agglutinin. Immunobiology, 212(7), 589-599.

9. Boggula, N., Elsani, M. M., \& Kaveti, V. S. (2018). Pharmacognostic, phytochemical analysis and antidiabetic activity of dried leaves of Abrus precatoriusAn in vivo approach. International Journal of Pharmaceutical Sciences and Drug Research, 10(3), $118-124$.

10. Monago, C. C., \& Nwodo, O. F. C. (2010). Antidiabetic effect of crude trigonelline of Abrus precatorius Linn seed in alloxan diabetic rabbits. Journal of Pharmacy Research,3(8), 19161919.

11. Rashmi, A., Gill, N. S., Sukhwinder, K., \& Jain, A. D. (2011). Phytopharmacological evaluation of ethanolic extract of the seeds of Abrus precatorius Linn. Journal of pharmacology and toxicology, 6(6), 580-588.

12. Georgewill, O. A., \& Georgewill, U. O. (2009). Evaluation of the anti-inflammatory activity of extract of Abrus precatorious. Eastern Journal of Medicine, 14(1), 23.

13. Bhakta, S., Awal, A., \& Das, S. K. (2019). Herbal contraceptive effect of Abrus precatorius, Ricinus communis, and Syzygium aromaticum on anatomy of the testis of male Swiss albino mice. J Adv Biotechnol Exp Ther, 2(2), 36-43.

14. Abu, S. M., Manirul, H. A., Majid, M. A., \& Anwarul, I. M. (2012). Antifertility studies on ethanolic extract of Abrus precatorius L on swiss male albino mice. International journal of pharmaceutical sciences and research, 3(1), 288.

15. Reddy Palvai, V., Mahalingu, S., \& Urooj, A. (2014). Canthium parviflorum leaves: antioxidant activity in food and biological systems, $\mathrm{pH}$, and temperature stability. Chinese Journal of Biology, 2014.

16. Umamaheswari, M., Dhinesh, S., Asokkumar, K., Sivashanmugam, T., Subhadradevi, V., Puliyath, J., \& Madeswaran, A. (2012). Anticataractic and antioxidant activities of Abrus precatorius Linn. Against calcium-induced cataractogenesis using goat lenses. Eur J Exp Biol, 2(2), 378-384.

17. Sohn, S. H., Lee, H., Nam, J. Y., Kim, S. H., Jung, H. J., Kim, Y., \& Bae, H. (2009). Screening of herbal medicines for the recovery of cisplatin-induced nephrotoxicity. Environmental Toxicology and Pharmacology, 28(2), 206-212.

18. Premanand, R., \& Ganesh, T. (2010). Neuroprotective effects of Abrus precatorius Linn. Aerial extract on hypoxic neurotoxicity induced rats. Int $J$ Chem Pharmac Sci, 1(1), 9-15.

19. Ménan, H., Banzouzi, J. T., Hocquette, A., Pélissier, Y., Blache, Y., Koné, M., \& Valentin, A. (2006). Antiplasmodial activity and cytotoxicity of plants used in West African traditional medicine for the treatment of malaria. Journal of ethnopharmacology, 105(1-2), 131-136.

20. Sathish, M., Balaji, R., Aruna, A., Niraimahi, V., Manikandan, G., \& Bose, M. (2010). Preliminary phytochemical and cytotoxic property on leaves of Abrus precatorius Linn. J Her Medi Toxicol, 4(1), 2124.

21. Chhabi, S. B., Sultana, S., Zaman, S., Abdullah, M., \& Islam, N. (2019). Biological activity of Abrus precatorius L. through Dose-mortality, repellent activity and Brine shrimp lethality tests.

22. Mobin, L., Saeed, S. A., Ali, R., SAEED, S. M. G., \& Ahmed, R. (2017). Antibacterial, antioxidant, and phenolic compound analyses of Abrus precatorius seed coat extract and its different fractions. Pak. J. Bot, 49(6), 2499-2506.

23. Mistry, K., Mehta, M., Mendpara, N., Gamit, S., \& Shah, G. (2010). Determination of antibacterial activity and MIC of crude extract of Abrus precatorius L. Adv Biotech, 10(2), 25-27.

24. Parvaiz, M., Hussain, K., Khalid, S., Hussnain, N., Iram, N., Hussain, Z., \& Ali, M. A. (2014). A review: Medicinal importance of Glycyrrhiza glabra L. (Fabaceae family). Global J Pharmacol, 8(1), 8-13.

25. Salehi, B., Kumar, N. V. A., Şener, B., Sharifi-Rad, M., Kılıç, M., Mahady, G. B., \& Ayatollahi, S. A. (2018). Medicinal plants used in the treatment of human immunodeficiency virus. International journal of molecular sciences, 19(5), 1459.

26. Ghosal, S., \& Dutta, S. K. (1971). Alkaloids of Abrus precatorius. Phytochemistry, 10(1), 195-198.

27. Bhardwaj, D. K., Bisht, M. S., \& Mehta, C. K. (1980). Flavonoids from Abrus precatorius. Phytochemistry. 19:2040-2041.

28. Ragasa, C. Y., Lorena, G. S., Mandia, E. H., Raga, D. D., \& Shen, C. C. (2013). Chemical constituents of Abrus precatorius. Amer J Essent Oils Nat Prod, 1(2), 7-10.

29. Bhatia, M., Siddiqui, N., \& Gupta, S. (2013). Abrus precatorius (L.): An evaluation of traditional herb. $J$ Pharm Res, 3, 3296-315.

30. Akinloye, B. A., \& LA, A. (1981). Abrus precatorius leaves-a source of glycyrrhizin. Niger J Pharm, 12, 405.

31. Wettstein, D. (1957). Formula of chlorophyll determination. Exp. Cell Res, 12(3), 427-489.

32. Jackson, M. L. (2005). Soil chemical analysis: Advanced course. UW-Madison Libraries Parallel Press.

33. Mandal, S., Banjanin, B.Kujović, I, Male Nica, M. (2015). Spectrophotometric determination of total iron content in black tea, Bulletin of the Chemists and Technologists of Bosnia and Herzegovina, 44:29-32

34. Lowry, O. H., Rosebrough, N. J., Farr, A. L., \& Randall, R. J. (1951). Protein measurement with the 
Folin phenol reagent. Journal of biological chemistry, 193, 265-275.

35. Zhishen, J., Mengcheng, T., \& Jianming, W. (1999). The determination of flavonoid contents in mulberry and their scavenging effects on superoxide radicals. Food chemistry, 64(4), 555-559.

36. Roberts, E. A. H. (1962). Economic importance of flavonoid substances: tea fermentation. The chemistry of flavonoid compounds, 468-512.

37. Yao, L., Caffin, N., D' Arcy. B., Jiang, Y., Shi, J., Singanusong, R., Liu, X., Datta, N., Kakuda, Y., \& $\mathrm{Xu}, \mathrm{Y}$. (2005). Seasonal variations of phenolic compounds in Australia-grown tea (Camellia sinensis), J. Agric. Food Chem, 53, 6477-6483.

38. Balentine, D. A., Wiseman, S. A., \& Bouwens, L. C. (1997). The chemistry of tea flavonoids. Critical Reviews in Food Science \& Nutrition, 37(8), 693-704.

39. Abdullah, S., \& Utra, U. (2015). Determination of phenolic and antioxidant properties in Tea and spent Tea under various extraction method and determination of Catechins, caffeine and Gallic Acid by HPLC. International Journal on Advanced Science, Engineering and Information Technology, 5(3), 158-164.

40. Sánchez-Moreno, C., Larrauri, J. A., \& Saura-Calixto, F. (1998). A procedure to measure the antiradical efficiency of polyphenols. Journal of the Science of Food and Agriculture, 76(2), 270-276.

41. Charu, G., \& Vandana, M. (2010). Effect of seasonal variation in photosynthetic pigments of few medicinal plants species of Jhansi. International Journal of Plant Sciences (Muzaffarnagar), 5(2), 676-678.

42. Shinde, H. P., Goswami, D. B. \& Ahire, P. P. (2016). Seasonal Variation of Chlorophyll Content in the Leaves of Some Medicinal Plants in Nashik. Indian J. Appl. Res. 6: 278-279.

43. Sauceda, J. U., Rodriguez, H. G., Lozano, R. R., Silva, I. C., Meza, M. V. G., \& Larga, L. (2008). Seasonal trends of chlorophylls $\mathrm{a}$ and $\mathrm{b}$ and carotenoids in native trees and shrubs of Northeastern Mexico. Journal of Biological Sciences, 8, 258-267.

44. Prajapati, S. K., \& Tripathi, B. D. (2008). Seasonal variation of leaf dust accumulation and pigment content in plant species exposed to urban particulates pollution. Journal of environmental quality, 37(3), 865-870.

45. Patarapanich, C., Laungcholatan, S., Mahaverawat, N., Chaichantipayuth, C., \& Pummangura, S. (2007). HPLC determination of active diterpene lactones from Andrographis paniculata Nees planted in various seasons and regions in Thailand. Thai $J$ Pharm Sci, 31(3-4), 91-9.
46. Uddin, M. S., Alam, K. M. M., \& Chowdhury, M. A. M.(2014) Seasonal effect on foliar photosynthetic pigments, nutrients and crude alkaloids of Andrographis paniculata (Burm.f.) Wall ex Nees. (Kalomegh). Sch. Acad. J. Biosci., 2(12C): 968-972

47. Zhu, L., Liu, X., Tan, J., \& Wang, B. (2013). Influence of harvest season on antioxidant activity and constituents of rabbiteye blueberry (Vaccinium ashei) leaves. Journal of agricultural and food chemistry, 61(47), 11477-11483.

48. Chowdhury, M. A., \& Alam, K. M. (2001). Screening for qualitative and quantitative status of green tea in ten clonal agro-types cultured at BTRISS, ODAHLEA, Bangladesh. In Proceedings of 2001 international conference on $\mathrm{O}-\mathrm{CHA}$ (tea) culture and science, Shizuoka, Japan. Session-II (production) (pp. 41-45).

49. Wahba, H. E., Sarhan, A. Z., Salama, A. B., SharafEldin, M. A., \& Gad, H. M. (2017). Effect of seasonal variation on the growth and chemical composition of Cynara cardunculus L. plants. J. Mater. Environ. Sci, 8, 318-323.

50. Thakur, S., \& Kapila, S. (2017). Seasonal changes in antioxidant enzymes, polyphenol oxidase enzyme, flavonoids and phenolic content in three leafy liverworts. Lindbergia, 40(5), 39-44.

51. Liao, X., Xu, H., Feng, P., Wang, Y., \& Huang, J. (2018). Evaluation of environment on polyphenols and flavonoids in Oxalis corymbosa extracts as a potential source of antioxidants. E\&ES, 170(5), 052034.

52. Rekha, K., Sivasubramanian, C., \& Thiruvengadam, M. (2015). Evaluation of polyphenol composition and biological activities of two samples from summer and winter seasons of Ligularia fischeri var. Spiciformis Nakai. Acta Biologica Hungarica, 66(2), 179-191.

53. Cao, Y., Fang, S., Fu, X., Shang, X., \& Yang, W. (2019). Seasonal variation in phenolic compounds and antioxidant activity in leaves of Cyclocarya paliurus (Batal.) Iljinskaja. Forests, 10(8), 624.

54. Cezarotto, V. S., Giacomelli, S. R., Vendruscolo, M. H., Vestena, A. S., Cezarotto, C. S., Da Cruz, R. C., \& Cruz, L. (2017). Influence of harvest season and cultivar on the variation of phenolic compounds composition and antioxidant properties in Vaccinium ashei leaves. Molecules, 22(10), 1603.

55. Uddin, M. S., Akter, F., \& Alam, K.M.M, (2019-20). Quantitative evaluation for foliar pigments, nutrients, flavonoids, polyphenol and antioxidant activity of Gynura procumbens (Lour). Merr. On different growing seasons. International Journal of Green and Herbal Chemistry, Vol.-9(1) Sec. B: 070-080. 